\title{
Streblocerus superserricaudatus sp. nov. from Venezuela
}

\author{
(Macrothricidae, Anomopoda, Crustacea)
}

\author{
N. N. Smirnov ${ }^{1}$, Haymara Alvarez ${ }^{2}$ \& Maria M. Castillo ${ }^{3}$ \\ ${ }^{1}$ Institute for Animal Evolutionary Morphology and Ecology of the Russian Academy of Sciences, Leninskiy \\ Prospekt 33, Moscow 117071, Russia \\ ${ }^{2}$ Universidad Simon Bolivar, Division de Ciencias Biologicas, Dpto. de Estudios Ambientales, Sartanejas, Baruta, \\ Edo. Miranda, Apartado postal N 89.000, Caracas 108 Venezuela \\ ${ }^{3}$ The University of Michigan, School of Natural Resources and Environment, Ann Arbor, MI 48109-1115, USA
}

Received 17 November 1993; in revised form 19 October 1994; accepted 14 December 1994

Key words: tropical Crustacea, Macrothricidae, Streblocerus superserricaudatus sp. nov., Venezuela

\begin{abstract}
A new species of the genus Streblocerus is described from Venezuela and compared with European, Newfoundland and Australian specimens. The geographical distribution of the genus is discussed.
\end{abstract}

The genus Streblocerus comprises peculiar, smallest macrothricids characterized mainly by a bent antennule bearing laterally a few strong setae, the gut making convolutions, and a short bilobed postabdomen. The type species $S$. serricaudatus (Fischer, 1849) was described from the vicinity of Sankt Petersburg. In 1901, the smallest species of this genus $S$. pygmaeus Sars, 1901 was described from material reared from mud collected in the neighbourhood of Sao Paulo (Brazil). S. pygmaeus is also found in the Orinoco basin (Lewis et al., 1990).

The genus was supposed to be Holarctic and Neotropical. In $1928 \mathrm{~S}$. serricaudatus was found in Australia by Brehm (1928), and a New Zealand population was named S. serricaudatus var. novae-zealandiae by Brehm (1928). Paggi (1976) published a convincing record of $S$. serricaudatus from Argentina (Province of Rio Negro). In the present study G. O. Sars' type material of $S$. pygmaeus and original material of $S$. minutus (syn. S. serricaudatus Fischer) were examined (both in alcohol, F18460 and F18703, respectively, in the Zoological Museum of the Oslo University, Norway). Fischer's type material of $S$. serricaudatus obviously does no longer exist.

More recent findings added $S$. inexpectatus Dumont, 1981 from a pond at the border of Sene-

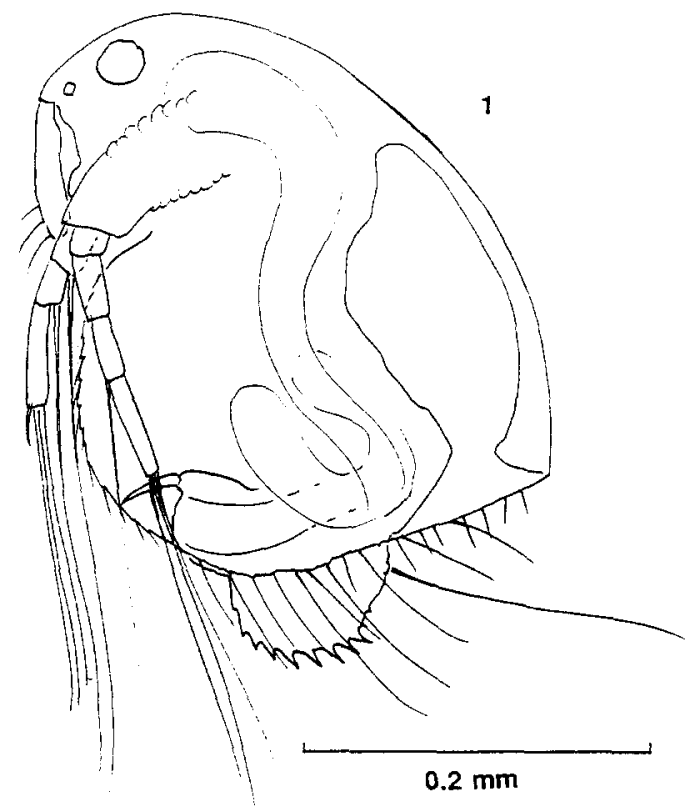

Fig. I. Streblocerus superserricaudatus sp. nov., left-side view (The Amazonas State).

gal and Guinea-Bissau (Africa). A form with a spinulated postabdomen was recorded from Malaysia by Idris \& Fernando (1981) and qualified as S. spinula- 


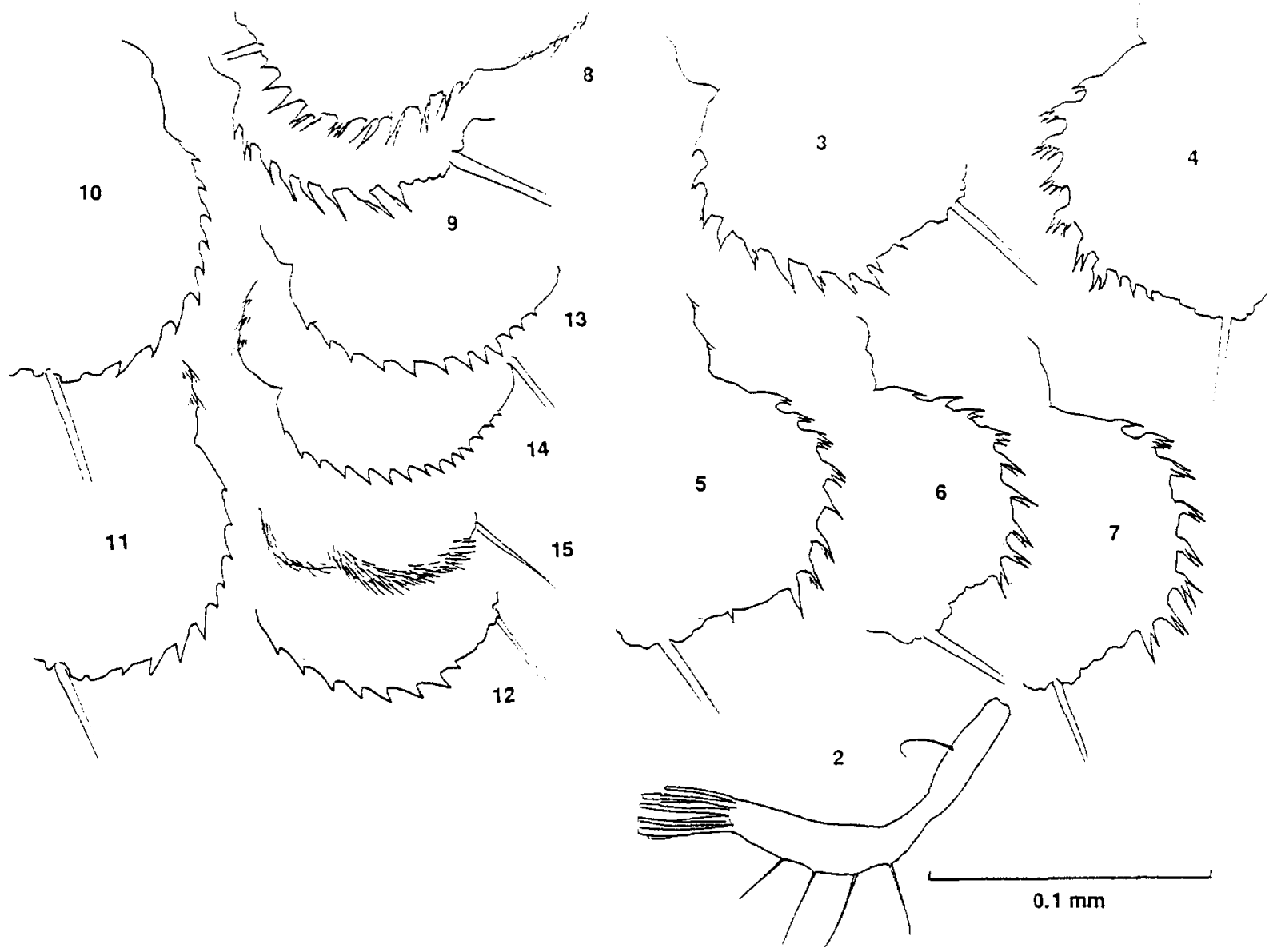

Plate 1. Its antennule (right, ventral view). Preanal margin of postabdomens. 3 - Preanal margin of the female shown in Fig. 1. 4-7 - Preanal margins of other females from the Amazonas State. 8-9 - Females from Estado Bolivar. 10-11 - Females of $S$. serricaudatus from a peat bog at Lake Narskoe (the Moscow region, Russia). 12 - Female of $S$. serricaudatus from Newfoundland (a pond at Bay Bulls). 13-14 - Females from Australia (New South Wales, a swamp inland from Sugar Point, Myall Lakes, 13-slide 2836, 14-slide 2836 in the Zoological Museum of the Moscow Univ.) 15 - S. pygmaeus from the Rio Nhamunda (Amazonas, Brazil, slide 3045).

tus by N. N. Smirnov, 1992. Thus, the distribution of the genus is cosmopolitan. However, few populations have been studied in detail and further investigation is necessary.

The known species differ mainly in the armament of the postabdomen (Figs 3-15). Specimens newly collected in Venezuela supplied a new link in the morphological series of postabdominal modification, which seemed to make a good reason to define a new species, described below. Sites where collections were made, hydrochemical data, and accompanied species are listed in the Table 1. The 'tepuis' are table mountains cut into Precambrian quartzite of the Roraima group' (Schubert 1988: 132).

\section{Streblocerus superserricaudatus sp. nov.}

(Figs 1-9)

Material. Females from highlands at c. $2000 \mathrm{~m}$ asl (tepuis) of the Guayana Shield in Venezuela: 6 females from the Amazonas State, 5 females from Estado Bolivar (Table 1) (collected by H. Alvarez and M. M. Castillo).

Holotype. A female from Territoria Federal Amazonas in the Zoological Museum of the Moscow University, N3701.

Paratypes. 5 females from Territorio Federal Amazonas, in the Zoological Museum of the Moscow University), NN 3702-3706. 
Table I.

\begin{tabular}{|c|c|c|c|c|c|c|}
\hline Site & Site description & Accompanying species & $\mathrm{pH}$ & $\begin{array}{l}\text { Conductivity } \\
\left(\mu \mathrm{Scm}^{-1}\right)\left(25^{\circ}\right)\end{array}$ & $\begin{array}{l}\text { Total alkalinity } \\
\left(\mathrm{mgCaCO}_{3} \mathrm{l}^{-1}\right)\end{array}$ & $\begin{array}{l}\text { Nitrate } \\
\left(\mu \mathrm{g}^{-1}\right)\end{array}$ \\
\hline $\begin{array}{l}\text { Auyar tepui } \\
\text { (Bolivar State) } \\
\text { Auyan river } \\
\text { Kukenan } \\
\text { (Bolivar State) }\end{array}$ & $\begin{array}{l}\text { Pond located } \\
\text { at a river turn }\end{array}$ & - & 4.98 & & 3.25 & 0.00 \\
\hline Pond 1 & $\begin{array}{l}\text { Shallow pond } \\
\text { (depth }<0.5 \mathrm{~m} \text { ) } \\
\text { with silty bottom }\end{array}$ & $\begin{array}{l}\text { Cyclopoid copepods } \\
\text { Cladocerans: } \\
\text { Acroperus harpae } \\
\text { Alonella nana } \\
\text { Chydorus piger } \\
\text { Unidentif. Chidorid } \\
\text { Rotiferans }\end{array}$ & 5.1 & 3.23 & 2 & 3 \\
\hline Pond 2 & $\begin{array}{l}\text { Shallow pond } \\
\text { (depth }<0.5 \mathrm{~m} \text { ) } \\
\text { bottom covered by } \\
\text { filamentous algae }\end{array}$ & $\begin{array}{l}\text { Acroperus harpae } \\
\text { Alona sp. } \\
\text { Rotiferans }\end{array}$ & 5.1 & 3.51 & 2.5 & 11 \\
\hline $\begin{array}{l}\text { Esmeralda } \\
\text { Lake } \\
\text { Roraima } \\
\text { (Bolivar State) }\end{array}$ & $\begin{array}{l}\text { Deeper (depth }+2 \mathrm{~m} \text { ) } \\
\text { pond with rocky bottom }\end{array}$ & $\begin{array}{l}\text { Acroperus harpae } \\
\text { Chydorus piger }\end{array}$ & 5.4 & 2.61 & 4 & 3.3 \\
\hline Lake Gladys & Pond & $\begin{array}{l}\text { Cyclopid copepod: } \\
\text { Tropocyclops prasinus } \\
\text { Cladocerans: } \\
\text { Acroperus harpae } \\
\text { Alonella nana } \\
\text { Alona sp. } \\
\text { Unidentif. Chidorid } \\
\text { Rotiferans }\end{array}$ & 5.3 & 2.81 & 2.5 & 3.3 \\
\hline \multicolumn{7}{|c|}{$\begin{array}{l}\text { Marahuaka } \\
\text { (Amazonas State) }\end{array}$} \\
\hline pond & $\begin{array}{l}\text { Shallow pond } \\
\text { (depth }<0.5 \mathrm{~m} \text { ) }\end{array}$ & $\begin{array}{l}\text { Cyclopoid and harpacticoid } \\
\text { copepods } \\
\text { Cladocerans: } \\
\text { Alonella nana } \\
\text { Alonella sp. } \\
\text { Alona sp. } \\
\text { Acantholeberis curvirostris } \\
\text { Rotiferans } \\
\text { Lecane lunaris }\end{array}$ & 3.9 & 5.9 & 0 & 0 \\
\hline
\end{tabular}

Female. With features of the genus. Dorsoposterior angle of shell noticeable. Antennule incurved, with 4 lateral setae and a short basal seta. Setae on the posterior part of ventral margin of valve intermittently short and long. Teeth on preanal margin of postabdomen elongated and pointed into filiform apices, frequently building groups. In several individuals the base of a tooth makes an elevated base bearing on its top a cluster of 2-4 denticles. Females from Estado Bolivar possess more elongated and spiniform preanal teeth (Figs 8,9). Length c. $0.36 \mathrm{~mm}$.

Male. Unknown. 
Type locality. A shallow pond at Marahuaka (The Amazonas State, Venezuela).

Ecology. S. superserricaudatus is found in lentic environments (like shallow ponds), and in a pond in the Auyan river, most probably permanent. The low $\mathrm{pH}$ of Auyan tepui and Marahuaka waters may be associated with a higher incidence of peat deposits here than in Roraima and Kukenan. Air temperature in the visited localities shows a rather high daily variation: e.g., 8$17^{\circ} \mathrm{C}$ in Kukenan.

Differential diagnosis. S. superserricaudatus sp. nov. has long, pointed and frequently clustered preanal teeth, while its nearest relative $S$. serricaudatus possesses solitary teeth, not elongated into filiform apex, as shown in Figs 10-12.

The new form was compared with European and Newfoundland specimens of $S$. serricaudatus, which both have solitary teeth increasing in size proximally. Specimens from Australia (New South Wales), studied for comparison, also possessed solitary preanal teeth, but the largest of them was situated in the middle, and teeth became smaller proximally as shown in Figs 13, 14. This may be also seen on the figure by Brehm (1928, Fig. 53) thus confirming his $S$. serricaudatus novae-zealandiae, with possible Australasian distribution (Smirnov \& Timms, 1983).

\section{Discussion}

No interpopulational comparative studies had been ever made on Streblocerus species. Especially in case of widely distributed species (e.g., S. serricaudatus Eurasia-wide, North American and South American) local taxa may be revealed, as was the case, e.g., with $S$. inexpectatus described by Dumont (1981) from West Africa. This species is generally close to $S$. serricaudatus, but differs in a deep cut between the distal and proximal lobes of the postabdomen.

Thus the genus Streblocerus supplies a peculiar case of geographical distribution: Holarctic, Australasian, Neotropical, with loci in Malaysia and Africa. It may be reminded that there are a number of other species of the Macrothricidae (Smirnov,
1992) and of other anomopods with clear Holarctic distribution and additionally occurring in the southern hemisphere. Extreme cases of morphological speciation (specialization) are now recorded for the Neotropical region such as $S$. superserricaudatus sp. nov., and $S$. pygmaeus. The distribution of $S$. serricaudatus (if its close relative $S$. inexpectatus be added) on all continents may be interpreted as an indication to ancient nature of this form.

\section{Acknowledgments}

We thank the Foundation Terramar for support during the expeditions organized by them. This study was partially supported by a grant from the $G$. Soros International Science Foundation to one of us (NNS).

\section{References}

Brehm, V., 1928. Fresh-water fauna of New Zealand, contributions to a knowledge of. Part I. On the microfauna of a pond in a Sphagnum-bog on Mount Rolleston. Trans. New Zealand Inst., V: 779-792.

Dumont, H. J., 1981. Cladocera and free-living Copepoda from the Fouta Djalon and adjacent mountain areas in West Africa. Hydrobiologia 85: 97-116.

Idris, B. A. G. \& C. H. Fernando, 1981. Cladocera of Malaysia and Singapore with new records, redescriptions, and remarks on some species. Hydrobiologia 77: 233-256.

Lewis, W. M., Jr., J. F. Saunders, III \& R. Dufford, 1990. Suspended organisms and biological carbon flux along the lower Orinoco river. In: Weibezahn, F. H., Alvarez, H., and Lewis, W. M., Jr. (eds), The Orinoco river as an ecosystem. Fondo Editorial Acta Cientifica Venezolana. C.A. Venezolana de Navegacion, and Universidad Simon Bolivar, Caracas.

Paggi, J. C., 1976. Cladoceros Macrothricidae nuevos para la fauna Argentina. Physis, seccion B: 103-112.

Schubert, C., 1988. Climatic changes during the last glacial maximum in northern South America and the Caribbean: a review. Interciencia, 13, 3: 128-137.

Smirnov, N. N., 1976. Macrothricidae and Moinidae of the World's fauna. Fauna SSSR, I, 3, New series N112. 237 pp (in Russian).

Smirnov, N. N., 1992. The Macrothricidae of the World. Guides to the identification of the microinvertebrates of the continental waters of the World 1. The Hague. $143 \mathrm{pp}$.

Smirnov, N. N. \& B. V. Timms, 1983. Revision of the Australian Cladocera (Crustacea). Records Austr. Museum. Supl. 1. 132 pp. 